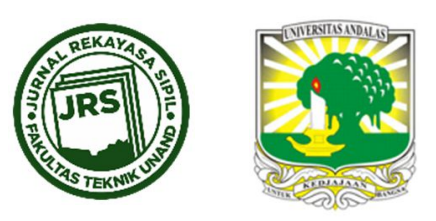

\title{
EVALUASI PENERAPAN SISTEM KESELAMATAN KEBAKARAN PADA GEDUNG-GEDUNG UMUM DI KOTA PAYAKUMBUH
}

\author{
YANOLLA MARETA ${ }^{1}$, BENNY HIDAYAT $^{1^{*}}$ \\ ${ }^{1}$ Jurusan Teknik Sipil, Fakultas Teknik, Universitas Andalas \\ *Corresponding author: $\bowtie$ bennyhidayat@eng.unand.ac.id \\ Naskah diterima : 22 Januari 2020. Disetujui: 24 April 2020.
}

\begin{abstract}
ABSTRAK
Gedung fasilitas umum seperti rumah sakit dan gedung perkantoran adalah contoh gedung dengan aktifitas yang cukup tinggi dimana memiliki berbagai kegiatan yang dapat memicu terjadinya bahaya kebakaran. Upaya mencegah terjadinya kebakaran pada gedung salah satunya yaitu dengan menyediakan sistem keselamatan kebakaran bangunan gedung yang baik. Untuk itu diperlukan evaluasi penerapan sistem keselamatan kebakaran dengan mengacu kepada pedoman pemeriksaan keselamatan kebakaran bangunan gedung (Pd-T-11-2005-C) yang dikeluarkan oleh Badan Litbang PU Departemen Pekerjaan Umum. Tujuan penelitian ini adalah untuk mengetahui kondisi keandalan sistem keselamatan bangunan terhadap bahaya kebakaran di gedung-gedung umum di kota Payakumbuh, dengan mengambil contoh tiga buah gedung fasilitias umum. Metode penelitian yang digunakan adalah observasi gedung dengan mempergunakan pedoman pemeriksaan keselamatan kebakaran bangunan gedung. Juga dilakukan wawancara dengan pihak pengelola gedung. Metode pengolahan data menggunakan metode kuantitatif untuk mengukur nilai keandalan sistem keselamatan bangunan (NKSKB) terhadap bahaya kebakaran berdasarkan buku pedoman (pd-T-112005-C). Hasil penelitian menunjukkan NKSKB pada gedung Rumah Sakit (A1) sebesar 81,81\% termasuk dalam kategori baik (B), gedung kantor pemerintahan (A2) 68,05\% termasuk dalam kategori cukup (C) dan gedung kantor organisasi perangkat daerah (A3) sebesar 59,19\% termasuk dalam kategori kurang $(\mathrm{K})$.
\end{abstract}

Kata kunci : Gedung, kebakaran, sistem proteksi aktif, sistem keselamatan, sarana penyelamatan, NKSKB

\section{LATAR BELAKANG}

Fasilitas umum seperti gedung rumah sakit, gedung kantor, sekolah, pusat perbelanjaan adalah beberapa bangunan gedung yang memiliki aktifitas yang memiliki risiko kebakaran cukup tinggi, seperti penggunaan bahan kimia berbahaya pada rumah sakit, penggunaan alat-alat listrik, serta tindakan kriminal yang disengaja yang dapat menimbulkan bahaya kebakaran. Bahaya kebakaran tidak hanya merusak bangunan gedung saja, namun dapat menyebabkan jatuhnya korban jiwa, dan kerugian materil seperti kehilangan aset dan harta 
benda didalamnya. Oleh karena itu perlu adanya kewaspadaan terhadap ancaman bahaya kebakaran sejak dini. Kebakaran bisa bermula dari kurangnya kesadaran masyarakat terhadap bahaya kebakaran yang dapat terjadi dimanapun dan kapanpun, dan kurangnya pemahaman tentang penanggulangan kebakaran dan kurangnya sistem proteksi kebakaran yang tersedia pada bangunan gedung khususnya fasilitas umum (Zulfiar \& Gunawan, 2018). Sistem proteksi kebakaran merupakan kelengkapan penting yang harus tersedia pada bangunan gedung khususnya fasilitas umum yang banyak melayani masyarakat dimana berfungsi sebagai usaha dan pencegahan rusaknya bangunan, jatuhnya korban jiwa dan kerugian aset atau harta benda (Kementerian Kesehatan RI, 2012).

Kota Payakumbuh adalah salah satu kota utama di Provinsi Sumatera Barat, kota penghubung antara Padang sebagai ibu kota provinsi dan Pekanbaru di Provinsi Riau. Kota ini merupakan kota perdagangan dengan pertumbuhan ekonomi tertinggi di Sumatera Barat. Dengan kegiatan perkekonomian dan pemerintahan yang tinggi, kebakaran adalah peristiwa yang sangat merugikan dan mengganggu perekonomian. Untuk pencegahan kebakaran, pemerintah sudah mengeluarkan berbagai aturan, salah satunya adalah pedoman pemeriksaan keselamatan kebakaran bangunan gedung (Pd-T-11-2005-C) yang dikeluarkan oleh Badan Litbang PU Departemen Pekerjaan Umum. Pedoman ini tentang sistem proteksi kebakaran pada bangunan gedung. Untuk itu diperlukan penelitian untuk mengindentifikasi seperti apa kondisi sistem kebakaran bangunan gedung fasilitas umum di Kota Payakumbuh terhadap bahaya kebakaran.

Penelitian ini bertujuan untuk menentukan nilai keandalan sistem keselamatan bangunan terhadap bahaya kebakaran pada gedung-gedung umum di kota Payakumbuh dengan mengacu kepada pedoman teknis pemeriksaan keselamatan bangunan terhadap bahaya kebakaran (Pd-T-11-2005-C) yang dikeluarkan oleh Badan Litbang Departemen Pekerjaan Umum.

\section{BAHAYA KEBAKARAN PADA BANGUNAN GEDUNG}

Bangunan gedung merupakan hasil dari kegiatan konstruksi yang menyatu dengan tempat kedudukannya baik itu sebagian atau seluruhnya berada diatas dan/ atau dibawah permukaan tanah dan/atau air yang dapat difungsikan oleh manusia sebagai tempat hunian ataupun melakukan kegiatan atau aktifitas seperti kegiatan usaha, keagamaan, kegiatan sosisal dan aktifitas lain sebagainya (Kementrian PU, 2008).

Kebakaran adalah sebuah fenomena yang terjadi ketika suatu bahan mencapai temperatur kritis dan bereaksi secara kimia dengan oksigen yang menghasilkan panas, nyala api, cahaya asap, uap air, karbonmonoksida, karbondioksida atau produk dan efek lain (Riadi, 2018). Ketika terjadi kebakaran ada tiga hal yang perlu diperhatikan yang berkaitan dengan bahaya api yang terjadi pada bangunan yang terbakar dan lingkungan bangunan yang berada disekitar, yaitu penghuni bangunan (manusia), isi bangunan (harta), struktur bangunan dan bangunan yang letaknya bersebelahan (Suwanda, Hidayat, \& Hesna, 2009).

\subsection{Sistem Proteksi Kebakaran}

Ada 4 komponen sistem proteksi kebakaran yang harus disediakan pada bangunan khususnya gedung dengan fasilitas umum:

1. Kelengkapan Tapak 
Komponen ini mengatur bagaimana letak dan posisi bangunan dengan lingkungan disekitarnya yang berkaitan dengan bahaya kebakaran dan bagaimana proses upaya untuk pemadamannya (Kementrian PU, 2008).

2. Sarana Penyelamatan

Komponen penting yang harus disediakan di dalam gedung adalah sarana penyelamatan yang dapat difungsikan oleh penghuni bangunan untuk melakukan penyelamatan diri dengan aman dan cukup waktu jika terjadi keadaan darurat seperti bahaya kebakaran (Kementrian PU, 2008).

3. Sistem Proteksi Aktif

Sistem proteksi aktif sangat diperlukan bagi setiap gedung khususnya fasilitas umum sebagai upaya untuk pencegahan kebakaran dimana sistem proteksi aktif seperti detektor, hidran gedung, alarm kebakaran, APAR, sprinkler, sistem pemadam luapan dapat membantu membatasi penjalaran api pada gedung sehingga kerugian yang disebabkan oleh kebakaran dapat diminimalisir.

a. Sistem Deteksi, yaitu sistem yang dilengkapi dengan alat detektor seperti detektor asap dan detektor panas yang berfungsi untuk mendeteksi indikasi awal adanya bahaya kebakaran secara dini.

b. Alarm kebakaran, alat ini dapat berfungsi secara otomatis untuk memberikan peringatan kepada penghuni gedung untuk melakukan penyelamatan diri atau evakuasi ketika terjadi kebakaran.

c. Hidran, alat ini adalah salah satu alat yang dapat membantu upaya pemadaman dengan cara mengalirkan air bertekanan melalui pipa dan slang kebakaran yang diletakkan di lokasi yang mudah dijangkau oleh petugas pemadam kebakaran dan disimpan dalam kotak baja bewarna merah.

d. Sprinkler, alat pemadam api yang berfungsi otomatis yang dapat mengeluarkan air ke segala arah ketika kepala sprinkler tersebut pecah setelah detektor mendeteksi adanya indikasi bahaya kebakaran seperti asap.

e. APAR (Alat Pemadam Api Ringan), alat ini digunakan untuk membantu pemadaman api yang masih kecil, yang dapat dibawa dan dioperasikan oleh satu orang (Harahap, 2018).

4. Sistem proteksi pasif mengatur tentang unsur komponen pembentuk struktur bangunan sesuai dengan tipe tingkat ketahanannya terhadap api, pembatasan penjalaran api dan proteksi bukaan yang tersedia guna untuk membatasi meluasnya penjalaran api dan asap akibat bahaya kebakaran (Kementrian PU, 2008).

\subsection{Penelitian Terdahulu}

Suwanda et al. (2009) melakukan penelitian tentang evaluasi penerapan sistem keselamatan kebakaran pada bangunan gedung Rumah Sakit DR.M.Djamil Padang. Dalam penelitian ini mereka menghitung dan menghasilkan NKSKB dengan nilai 82,17\%, yang mengindikasikan gedung rumah sakit tersebut memiliki tingkat keandalan masih berada dalam kondisi baik. Penelitian lain tentang keandalan sistem kebakaran gedung rumah sakit dilakukan oleh Pratama dan Trikomara (2017). Penelitian mereka tentang analisis keandalan sistem keselamatan bangunan terhadap bahaya kebakaran, dengan studi kasus gedung RSIA Eria Bunda Kota Pekanbaru. Penelitian ini memberikan hasil perhitungan NKSKB dengan nilai $57,24 \%$ dimana tingkat keandalan bangunan berada dalam kondisi kurang $(\mathrm{K})$ karena tidak ketersediaan komponen dan tidak sesuai dengan kriteria peraturan (Pratama \& Trikomara, 2017).

Penelitian lain berjudul Evaluasi Sistem dan Manajemen Proteksi Kebakaran Gedung Rumah Sakit di Kota Medan (Studi Kasus RS USU dan RS Bunda Thamrin). Penelitian ini memberikan hasil perhitungan NKSKB dengan nilai 93,93\% untuk RS USU dan 93,27\% 
untuk RS Bunda Thamrin. Namun untuk gedung rumah sakit USU tidak memiliki manajemen proteksi kebakaran masuk dalam kategori kurang $(\mathrm{K})$ karena dari variable proses tanggap darurat, organisasi proteksi kebakaran dan sumber daya manusia memiliki tingkat kesesuaian 0\% dengan Permen PU No.26/PRT/M/2009, sedangkan RS Bunda Thamrin masuk dalam kategori baik (B) karena memiliki tingkat kesesuaian $87,6 \%$ dengan Permen PU No.26/PRT/M/2009 (Harahap, 2018).

Untuk gedung pemerintahan, ada penelitian yang dilakukan oleh Trikomara, Sebayang dan Mahmudah (2012) yang berjudul Evaluasi Keandalan Sistem Proteksi Kebakaran Pada Bangunan Gedung (Studi Kasus Gedung Kantor Bupati Indragiri Hilir). Penelitian ini memberikan hasil perhitungan NKSKB dengan nilai 79,07\% dimana tingkat keandalan bangunan ini berada dalam kondisi cukup (C). Untuk mengembalikan kondisi cukup menjadi baik maka pihak pengelola gedung dapat mengidentifikasi dan melengkapi kekurangan sistem proteksi kebakaran gedung.

Untuk gedung komersil seperti apartemen, ada penelitian oleh Kurniawati (2012) yang meneliti tentang evaluasi sistem proteksi kebakaran pada bangunan apartemen. Kurniawati meninjau sarana penyelamatan dan sistem proteksi pasif dengan mengambil studi kasus geudng apartemen Solo Paragon. Penelitian ini memberikan hasil perhitungan NKSKB dengan nilai 92,35\%, hasil ini menunjukkan bahwa nilai keandalan bangunan dalam kondisi baik dan sesuai dengan peraturan yang berlaku (Kurniawati, 2012). Penelitian yang serupa dilakukan oleh Zulfiar dan Gunawan Zulfiar and Gunawan (2018) yang meneliti tentang sistem proteksi kebakaran pada bangunan hotel UNY yang terdiri dari lima lantai di Yogyakarta. Penelitian ini memberikan hasil perhitungan NKSKB dengan nilai 91,6 \% dimana tingkat keandalan bangunan gedung hotel UNY berada dalam kondisi baik (B) (Zulfiar \& Gunawan, 2018).

\section{METODOLOGI PENELITIAN}

Untuk mengetahui bagaimana penerapan sistem proteksi kebakaran pada gedung-gedung umum di kota Payakumbuh, dilakukan melakukan pengamatan langsung dengan menggunakan metode deskriptif dan dilakukan pengukuran nilai keandalan sistem keselamatan bangunan (NKSKB) untuk bangunan gedung tersebut.

\subsection{Objek Penelitian}

Objek penelitian berjumlah 3 buah gedung yang terdiri dari 1 buah gedung rumah sakit dengan empat lantai (diberi kode dalam penelitian ini A1), dan 2 buah gedung perkantoran (diberi kode A2 dan A3) yang masing-masing terdiri tiga lantai. Gedung-gedung ini dijadikan objek penelitian karena ketiga gedung ini adalah gedung fasilitas umum dengan aktifitas yang cukup tinggi dalam pelayanan masyarakat di Kota Payakumbuh sehingga diperlukan evaluasi terhadap penerapan sistem keselamatan bangunan pada gedunggedung tersebut terhadap bahaya kebakaran.

\subsection{Pengumpulan Data dan Instrumen Penelitian}

Pengumpulan data dilakukan dengan cara observasi, melakukan pengamatan langsung terhadap kondisi nyata sarana dan prasarana sistem proteksi kebakaran yang ada pada gedung. Dalam obervasi dilakukan pemeriksaan dengan menggunakan lembar daftar periksa (checklist) berdasarkan pedoman pemeriksaan keselamatan kebakaran bangunan gedung (Pd-T-11-2005-C) yang dikeluarkan oleh Balitbang Kementrian PU. Dilakukan juga pengukuran dimensi-dimensi pada gedung dengan menggunakan meteran, untuk 
konfirmasi pengisian nilai pada daftar periksa. Setiap komponen bangunan gedung didokumentasikan dengan kamera untuk untuk dokumentasi dan pengecekan ulang hasil perhitungan. Disamping obervasi, juga dilakukan wawancara dengan narasumber pengelola gedung. Wawancara berguna guna validasi data yang telah didapatkan melalui observasi sistem proteksi kebakaran gedung, dan mendapatkan data dan informasi mengenai manajemen proteksi kebakaran gedung yang diteliti.

\subsection{Variabel Penelitian}

Ada empat komponen penelitian sistem keselamatan kebakaran yang digunakan dalam penelitian ini:

1. Kelengkapan Tapak, variabel ini berkaitan dengan kondisi letak bangunan dan bagaimana upaya pemadaman jika terjadi kebakaran yang menyangkut sumber air, jalan lingkungan, jarak antar bangunan dan hidran halaman.

2. Sarana Penyelamatan, variabel ini berkaitan dengan sarana jalan keluar yang disediakan bagi penghuni gedung sehingga memiliki waktu yang cukup untuk menyelamatan diri dengan aman pada kondisi darurat seperti akses jalan keluar, konstruksi jalan keluar, landasan helikopter jika diperlukan.

3. Sistem Proteksi Aktif, variabel ini berkaitan dengan alat proteksi kebakaran yang terpasang pada gedung guna untuk upaya pencegahan kebakaran maupun pemadaman seperti detektor asap, hidran gedung, alarm kebakaran, APAR, sprinkler dan sistem pemadam luapan.

4. Sistem Proteksi Pasif, variabel ini berkaitan dengan komponen pembentuk struktur bangunan sesuai dengan tingkat ketahanannya terhadap api seperti ketahanan api dan stabilitas, kompartemenisasi dan pemisahan serta proteksi bukaan.

\subsection{Kriteria Penilaian}

Penilaian terhadap komponen sistem keselamatan bangunan terhadap bahaya kebakaran dibagi menjadi 3 kategori penilaian seperti yang dijelaskan pada tabel berikut :

Tabel 1. Tingkat penilaian audit kebakaran

\begin{tabular}{lll}
\hline Nilai & Kesesuaian & Keandalan \\
\hline$>80-100$ & Sesuai persyaratan & Baik (B) \\
\hline $60-80$ & $\begin{array}{l}\text { Terpasang tetapi ada sebagian kecil } \\
\text { instalasi yang tidak sesuai persyaratan }\end{array}$ & Cukup (C) \\
\hline$<60$ & Tidak sesuai sama sekali & Kurang (K) \\
\hline Sumber : (Puslitbang Pemukiman dan Balitbang, 2005) &
\end{tabular}

Ekuivalensi nilai $\mathrm{B}=100$, nilai $\mathrm{C}=80$ dan nilai $\mathrm{K}=60$, dan untuk sub-variable yang tidak tersedia dengan nilai=0. Karena ada empat komponen utama penilaian maka pembobotan parameter komponen yang digunakan adalah berdasarkan tabel berikut :

Tabel 2. Pembobotan Parameter Komponen Sistem Keselamatan Bangunan

\begin{tabular}{clc}
\hline No & Parameter KSKB & Bobot KSKB (\%) \\
\hline 1 & Kelengkapan Tapak & 25 \\
\hline 2 & Sarana Penyelamatan & 25 \\
\hline 3 & Sistem Proteksi Aktif & 24 \\
\hline 4 & Sistem Proteksi Pasif & 26 \\
\hline & Sumber : (Puslitbang Pemukiman dan Balitbang, 2005)
\end{tabular}


Setelah obervasi gedung maka dilakukan pengolahan data dan dilakukan perhitungan untuk menentukan nilai keandalan utilitas sebuah gedung berdasarkan pedoman pemeriksaan keselamatan bangunan gedung terhadap bahaya kebakaran (Pd-T-11-2005-C). Rumus untuk perhitungan nilai kondisi sebagai berikut:

Nilai kondisi $=($ Hasil Penilaian sub-KSKB $) \times($ Bobot sub-KSKB $) \times($ Bobot KSKB $)$

Setelah didapatkan Nilai Kondisi maka dialkukan perhitungan nilai keandalan sistem keselamatan bangunan dengan menggunakan rumus :

Nilai keandalan $(\mathrm{NKSKB})=\mathrm{KT}+\mathrm{SP}+\mathrm{SPA}+\mathrm{SPP}$

Keterangan :

NKSKB : Nilai Keandalan Sistem Keselamatan Bangunan

KT : Kelengkapan Tapak

SP : Sarana Penyelamatan

SPP : Sistem Proteksi Pasif

SPA : Sistem Proteksi Aktif

\section{HASIL DAN PEMBAHASAN}

Hasil perhitungan Nilai Keandalan Sistem Keselamatan Bangunan (NKSKB) untuk gedung rumah sakit (A1) secara umum berada dalam kategori baik (B), dengan perolehan NKSKB $81,81 \%$. Untuk gedung kantor (A2) mendapatkan NKSKB (71,34\%) dengan kategori cukup (C) dan gedung kantor (A3) mendapatkan hasil penilaian NKSKB (62,94\%) dengan kategori cukup (C). Berikut adalah kondisi pada tiap komponen penelitian untuk ketiga gedung penelitian tersebut.

\subsection{Kelengkapan Tapak}

Pada komponen kelengkapan tapak pada gedung rumah sakit (A1) secara umum telah terlaksana dengan baik sesuai dengan persyaratan dengan perolehan bobot yaitu $23,85 \%$. Untuk gedung kantor (A2) dan gedung kantor (A3) mendapatkan perolehan bobot $18,75 \%$.

\section{a. Sumber Air}

Sumber air pada ketiga gedung penelitian sama-sama berasal dari air PDAM. Pasokan air yang berada pada gedung rumah sakit (A1) disimpan dalam bak reservoir dengan kapasitas $100 \mathrm{~m}^{3}$ yang mampu mencukupi kebutuhan minimal fungsi bangunan. Minimal kebutuhan air untuk gedung rumah sakit adalah 500 liter/tempat tidur/hari. Pada gedung kantor A2 dan gedung kantor A3 sumber air telah disediakan dengan baik dan disimpan dalam bak reservoir dengan kapasitas $20 \mathrm{~m}^{3}$ yang dapat mencukupi kebutuhan minimal air sesuai dengan fungsi bangunan. Minimal kebutuhan air untuk gedung perkantoran adalah 50 liter/pegawai/hari (Badan Standarisasi Nasional, 2005).

\section{b. Jalan Lingkungan}

Persyaratan minimal lebar jalan lingkungan adalah 6 meter. Jalan lingkungan pada ketiga gedung penelitian telah tersedia dengan baik. Lebar jalan lingkungan yang tersedia pada gedung rumah sakit (A1) adalah $7 \mathrm{~m}$. Jalan lingkungan juga telah diberi perkerasan beton. Jalan lingkungan pada gedung kantor A2 juga telah tersedia dengan baik dengan lebar jalan 
7,2 m. Untuk gedung kantor A3 telah tersedia jalan lingkungan dengan lebar $8 \mathrm{~m}$. Untuk jalan lingkungan yang ada pada gedung kantor A2 dan A3 telah sama-sama diberi perkerasan (aspal) sehingga memberikan akses yang mudah untuk petugas pemadam kebakaran melakukan operasi pemadaman jika terjadi kebakaran.

\section{c. Jarak Antar Bangunan}

Berdasarkan kriteria peraturan persyaratan jarak antar bangunan dengan tinggi bangunan 14. sampai 40m yaitu dengan jarak 6 sampai $8 \mathrm{~m}$. Gedung rumah sakit (A1) memiliki tinggi bangunan $17,05 \mathrm{~m}$. Jarak bangunan terdekat dari gedung rumah sakit (A1) tersedia namun belum memenuhi kriteria yaitu dengan jarak $3 \mathrm{~m}$ saja. Pada gedung kantor A2 memiliki ketinggian 13,4m, jarak bangunan terdekat yaitu dengan jarak $8 \mathrm{~m}$ sehingga telah memenuhi kriteria. Untuk gedung kantor A3 dengan tinggi bangunan 13,5 m memiliki jarak bangunan terdekat dengan jarak $4 \mathrm{~m}$. Jarak antar bangunan perlu diperhatikan karena ketika terjadi bahaya kebakaran maka penjalaran api akan sangat mungkin terjadi ke bangunan yang terdekat yang berada disekitarnya.

\section{d. Hidran Halaman}

Hidran halaman yang tersedia pada gedung rumah sakit (A1) telah tersedia dengan baik dimana gedung dilengkapi dengan 3 hidran halaman yang berada disisi samping kanan, kiri dan belakang gedung. Hidran halaman ditempatkan di lokasi yang dapat dijangkau oleh petugas pemadam kebakaran, dan berfungsi dengan baik. Sementara untuk gedung kantor A2 dan A3 tidak tersedia sama sekali. Hidran halaman sebaiknya disediakan pada tiap gedung bertingkat yang sangat membantu petugas pemadam kebakaran dalam melakukan proses pemadaman karena dengan adanya hidran halaman yang berfungsi dengan baik dan didukung oleh panel yang lengkap serta distribusi air yang bertekanan pemadam kebakaran dapat memaksimalkan proses pemadaman sehingga pemadaman dapat dilakukan dengan cepat dan kerugian dapat diminimalisir.

\subsection{Sarana Penyelamatan}

Untuk komponen sarana penyelamatan gedung rumah sakit (A1) mendapatkan nilai 18,25\%, gedung kantor A2 dan gedung kantor A3 mendapatkan bobot nilai yang sama yaitu sebesar $16,5 \%$. Sarana penyelamatan sangat penting disediakan pada setiap gedung untuk upaya penghuni gedung dalam melakukan evakuasi dengan aman dengan waktu yang cukup.

\section{a. Sarana Jalan Keluar}

Tersedia 3 sarana jalan keluar pada gedung rumah sakit (A1) yaitu jalan keluar menuju pintu utama, jalan keluar menuju tangga darurat diluar bangunan dan jalan keluar menuju ramp. Sarana jalan keluar telah terlindung dari bahaya kebakaran dan akses menuju ruangan terbuka yang memudahkan penghuni bangunan dalam penyelamatan diri ke tempat yang aman. Pada gedung kantor A2 juga telah tersedia empat sarana jalan keluar yang telah terlindung dari bahaya kebakaran, akses menuju ke ruangan terbuka. Untuk gedung kantor A3 disediakan 3 jalan keluar yang juga terlindung dari bahaya kebakaran dan akses menuju ke ruangan terbuka. Sarana jalan keluar sangat membantu peghuni gedung dalam melakukan evakuasi secara aman.

\section{b. Konstruksi Jalan Keluar}

Secara umum gedung rumah sakit (A1), gedung kantor A2, dan gedung kantor A3 samasama memiliki konstruksi yang terbuat dari beton yang tahan terhadap api minimal 2-3 jam. 
Jalan keluar telah bebas halangan. Jalan terusan juga telah terlindung dari bahaya kebakaran dan bahan tidak mudah terbakar. Langit-langit juga telah memiliki ketahanan terhadap api karena terbuat dari beton dan dilapisi dengan plafon gypsum. Akses ke bangunan juga telah disediakan oleh ketiga gedung bagi tindakan petugas pemadam kebakaran. Sementara untuk persyaratan lebar tangga darurat yang disediakan oleh gedung rumah sakit (A1) telah memenuhi persyaratan dengan lebar 1,8 meter. Untuk gedung kantor A1 dan gedung kantor A2 sama-sama belum memenuhi persyaratan standar lebar minimal tangga darurat. Konstruksi jalan keluar sangat menentukan keamanan penghuni bangunan ketika melakukan evakuasi atau penyelamatan diri. Konstruksi jalan keluar yang baik yaitu dapat menahan asap dan penjalaran api dalam waktu tertentu dan mampu bertahan secara struktural ketika terjadi kerusakan pada elemen tertentu.

\section{c. Landasan Helikopter}

Untuk ketiga gedung penelitian sama-sama tidak memiliki landasan helikopter. Syarat diwajibkannya penggunaan landasan helikopter yaitu bangunan dengan tinggi minimal 60 meter. Ketiga bangunan penelitian memiliki ketinggian kurang dari 20 meter sehingga belum memerlukan landasan helikopter.

\subsection{Sistem Proteksi Aktif}

Sistem proteksi aktif yang tersedia pada gedung rumah sakit (A1) yaitu dengan bobot 17,04\%. Gedung kantor A2 memperoleh bobot 10,13\% dan gedung kantor A3 mendapatkan bobot terendah yaitu $2,93 \%$. Bobot kedua gedung kantor ini sangat jauh dari bobot standar, karena besarnya persentase tidak tersedianya sub variabel komponen ini pada gedung kantor A2 dan A3. Tidak ketersediaan sub komponen ini menurut hasil wawancara karena terbatasnya pagu anggaran untuk pengadaannya.

\section{a. Deteksi dan Alarm}

Alat proteksi ini telah terpasang pada bangunan gedung rumah sakit (A1), pada gedung kantor A2 juga telah disediakan namun belum pernah dilakukan uji coba pada alat ini. Untuk gedung kantor A3 tidak disediakan sama sekali. Detektor berfungsi mendeteksi secara dini adanya bahaya kebakaran yang juga terhubung dengan alarm untuk memberikan peringatan kepada penghuni gedung untuk menyelamatkan diri berupa bunyi atau tanda yang terlihat jelas oleh mata.

\section{b. Siamese Connection}

Telah disediakan siamese conection hanya pada gedung rumah sakit (A1) yang diletakkan di halaman dilokasi yang mudah dijangkau oleh pemadam kebakaran. Siamese connection sangat diperlukan ketika pasokan air yang ada pada gedung untuk operasi pemadaman tidak mencukupi maka dapat disambungkan dengan slang pemadam kebakaran dengan sumber air dari mobil pemadam kebakaran. Untuk gedung kantor A2 dan gedung kantor A3 belum tersedia siamese connection sama sekali.

\section{c. APAR}

APAR adalah alat pemadam api yang dapat dibawa dan dioperasikan oleh satu orang untuk kebakaran dengan api yang masih kecil. APAR telah disediakan hanya pada bangunan gedung rumah sakit (A1) dengan jarak penempatan alat tidak lebih dari $25 \mathrm{~m}$. APAR yang digunakan adalah jenis bubuk kimia kering. Tidak tersedia APAR pada kedua gedung lainnya, di gedung kantor A2 dan gedung kantor A3. 


\section{d. Hidran Gedung}

Hidran gedung telah disediakan pada gedung rumah sakit (A1) dan gedung kantor A2 dengan peralatan lengkap dan terhubung ke pompa distribusi air bertekanan. Sedangkan pada gedung kantor A3 tidak disediakan sama sekali hidran gedung.

e. Sprinkler

Dalam obervasi ditemukan bahwa tidak tersedia sprinkler pada ketiga gedung penelitian (A1,A2,dan A3). Sprinkler sangat membantu untuk membatasi penjalaran api terhadap bahaya kebakaran. Untuk gedung minimal 2 lantai keatas sebaiknya memasang sistem sprinkler sebagai upaya pencegahan penjalaran api kebakaran guna untuk meminimalisir kerugian yang diakibatkan oleh kebakaran.

\section{f. Sistem pemadam luapan}

Tidak disediakan sistem pemadam luapan pada ketiga gedung penelitian (A1,A2, dan A3). Padahal sistem pemadam luapan dapat melindungi ruangan khusus seperti ruangan komputer, ruang arsip yang ada pada gedung perkantoran.

\section{g. Pengendali Asap}

Sebaiknya disediakan pengendali asap pada ruangan yang membutuhkan udara segar. Pada gedung rumah sakit (A1) telah tersedia pengendali asap pada ruangan tertentu, kemudian pada gedung kantor A2 disediakan exhaust fan manual untuk ruangan dapur. Pada gedung kantor A3 tidak tersedia pengendali asap sama sekali.

\section{h. Deteksi Asap}

Deteksi asap telah tersedia dengan baik pada gedung rumah sakit (A1) dan gedung kantor A2 dengan jarak antara detektor tidak lebih 20m, namun pada gedung kantor A3 belum tersedia detektor asap sama sekali.

\section{i. Cahaya darurat dan Petunjuk arah}

Telah disediakan pencahayaan darurat pada disetiap sarana jalan keluar seperti tangga darurat, koridor dan jalan terusan dengan pencahayaan yang cukup pada ketiga gedung penelitian, namun untuk petunjuk arah hanya tersedia pada bangunan gedung rumah sakit (A1) saja. Untuk gedung kantor A2 dan gedung kantor A3 belum dilengkapi dengan petunjuk arah sama sekali. Cahaya darurat dan petunjuk arah membantu penghuni bangunan ketika melakukan evakuasi sehingga tidak kebingunan mencari jalan keluar dan dengan pencahayaan yang cukup.

\section{j. Listrik Darurat}

Sumber daya listrik utama pada ketiga gedung penelitian berasal dari PLN. Sumber daya lsitrik darurat juga telah disediakan pada ketiga gedung penelitian yaitu generator yang berfungsi otomatis ketika sumber daya utama padam.

k. Ruang pengendali operasi

Pada ruangan kontrol gedung dengan peralatan yang lengkap hanya disediakan pada gedung rumah sakit (A1) dan gedung kantor A2, beserta dengan petugas jaga yang dapat memantau 
bahaya kebakaran yang terjadi. Namun untuk gedung kantor A3 belum disediakan dengan peralatan yang lengkap.

\subsection{Sistem Proteksi Pasif}

Sistem proteksi pasif yang ada pada ketiga gedung penelitian belum dapat dikategorikan sempurna karena ada sub komponen yang tidak terpenuhi. Bobot maksimum untuk sistem proteksi pasif adalah $26 \%$. Pada gedung rumah sakit (A1) dan gedung kantor A2 mendapatkan nilai bobot yang sama yaitu 22,67\%. Namun untuk gedung kantor A3 memperoleh nilai $21,01 \%$.

a. Ketahanan Api dan Struktur Bangunan

Struktur bangunan ketiga gedung penelitian yaitu gedung rumah sakit (A1), gedung kantor A2 dan gedung kantor A3 terbuat dari beton bertulang yang tahan terhadap api sehingga dapat membantu penghuni bangunan dalam melakukan evakuasi dengan waktu yang cukup karena bangunan dapat bertahan secara structural dalam waktu tertentu

\section{b. Kompartemenisasi Ruang}

Pada ketiga gedung rumah sakit (A1), gedung kantor A2 dan gedung kantor A3 telah disediakan kompartemenisasi ruang yang telah terlaksana dengan baik sesuai dengan kelas bangunan. Dengan adanya kompartemenisasi ruang yang tersedia maka akan sangat menguntungkan untuk ketiga gedung tersebut dalam melakukan evakuasi penghuni bangunan secara aman dengan cukup waktu serta terlindungnya aset yang berada dalam bangunan gedung. Namun untuk ketiga gedung belum dilengkapi dengan sprinkler sebagai salah satu usaha untuk pemadaman dan penjalaran api.

\section{c. Perlindungan Bukaan}

Telah tersedia proteksi bukaan pada ketiga gedung penelitian yaitu gedung rumah sakit (A1), gedung kantor A2 dan gedung kantor A3 dimana semua lubang utilitas diberi penyetop api. Bukaan vertikal pada bangunan untuk saf pipa, saf ventilasi, saf instalasi listrik sepenuhnya tertutup dengan dinding dari bawah sampai atas dan tertutup setiap lantainya. Namun untuk semua gedung penelitian belum menyediakan pintu yang mampu menahan asap pada suhu tertentu dan belum mempunyai tingkat isolasi minimal 30 menit. Dengan tersedianya pintu penahan asap juga dapat membantu proses evakuasi berjalan dengan lancar karena dapat mengisolasi jalan keluar dari asap kebakaran dalam waktu tertentu sehingga dapat menghindari jatuhnya korban dan meminimalisir kerugian yang terjadi.

\section{KESIMPULAN DAN SARAN}

Dalam penelitian ini dilakukan obervasi dan perhitungan keandalan sistem keselamatan gedung terhadap bahaya kebakaran pada ketiga gedung yaitu gedung rumah sakit (A1), gedung kantor A2 dan A3, dan dapat disimpulkan:

1. Tingkat keandalan sistem proteksi kebakaran bangunan gedung rumah sakit (A1) terhadap bahaya kebakaran secara keseluruhan berada dalam kondisi baik (B) dengan NKSKB (Nilai Keandalan Sistem Keselamatan Bangunan) 81,81\%. Tingkat keandalan sistem proteksi kebakaran bangunan untuk gedung kantor A2 secara keseluruhan berada dalam kondisi cukup (C) yaitu dengan NKSKB 68,05\%. Sementara Tingkat keandalan sistem proteksi kebakaran bangunan untuk gedung kantor (A3) berada dalam kondisi kurang (K) dengan hasil NKSKB 59,19\% 
2. Terdapat perbedaan hasil NKSKB untuk ketiga gedung tersebut. Terdapat perbedaan signifikan pada komponen sistem proteksi aktif pada tiap gedung. Gedung rumah sakit (A1) mendapatkan nilai kondisi sistem proteksi aktif 17,04\%, gedung kantor A2 10,13\% dan gedung kantor A3 mendapatkan nilai kondisi terendah yaitu 2,93\% karena tidak ketersediaan sebagian besar sub komponen sistem proteksi aktif yang disebabkan oleh terbatasnya pagu anggaran untuk pengadaannya.

3. Rekomendasi untuk gedung rumah sakit (A1) bahwa ada beberapa sub komponen pada sistem proteksi aktif dan sistem proteksi pasif yang harus dilengkapi oleh pengelola gedung untuk memenuhi nilai keandalan sistem keselamatan bangunan menjadi sempurna. Selanjutnya rekomendasi untuk gedung kantor A2 dengan nilai cukup (C) dan gedung kantor A3 dengan nilai kurang (K) maka untuk mengembalikan nilai kondisi gedung menjadi baik (B) ada beberapa komponen yang harus dilengkapi oleh pengelola gedung yaitu komponen kelengkapan tapak, sistem proteksi aktif dan sistem proteksi pasif.

Salah satu keterbatasan dari penelitian ini adalah dalam melakukan observasi tidak dapat dilakukan pengecekan pengoperasian langsung terhadap fungsi dari alat-alat proteksi kebakaran karena kebijakan dan aturan dari pengelola gedung. Dalam penelitian ini dilakukan validasi data observasi dengan cara wawancara dengan pengelola gedung yang bersangkutan.

Berdasarkan pengalaman observasi dalam melakukan pengecekan kriteria pemeriksaan sistem keselamatan bangunan gedung menggunakan pedoman pemeriksaan keselamatan bangunan terhadap bahaya kebakaran (Pd-T-11-2005-C) yang dikeluarkan oleh Badan Litbang Departemen PU, agar dapat diklarifikasi kriteria penilaian tiap sub komponen gedung sesuai dengan kelas bangunan/ fungsi bangunan. Ini untuk mempermudah dalam penilaian sehingga penilaian dan hasil lebih akurat sesuai dengan kelas bangunan yang di audit. Kemudian untuk analisis data penentuan ekuivalensi kriteria kategori penilaian sebaiknya diklasifikasikan lebih detail seperti ekuivalensi penilaian untuk setiap sub komponen yang tidak tersedia.

\section{DAFTAR PUSTAKA}

Badan Standarisasi Nasional. (2005). SNI-03-7065-2005 tentang Tata cara perencanaan sistem plambing.

Harahap, H. K. (2018). Evaluasi Sistem dan Manajemen Proteksi Kebakaran Gedung Rumah Sakit Di Kota Medan. Universitas Sumatera Utara Medan, Medan. Retrieved from http://repositori.usu.ac.id/handle/123456789/11070

Kementerian Kesehatan RI. (2012). Pedoman Teknis Prasarana Rumah Sakit Sistem Proteksi Kebakaran Aktif.

Kementrian PU. (2008). Permen PU No.26/PRT/M/2008 tentang Persyaratan teknis sistem proteksi kebakaran pada bangunan gedung dan lingkungan.

Kurniawati, E. (2012). Evaluasi Sistem Proteksi Kebakaran Pada Bangunan Apartemen Ditinjau dari Sarana Penyelamatan dan Sistem Proteksi Pasif. Universitas Sebelas Maret, Surakarta.

Pratama, R., \& Trikomara, R. (2017). Analisis Keandalan Sistem Keselamatan Bangunan Terhadap Bahaya Kebakaran (Studi Kasus:Gedung RSIA Eria Bunda Kota Pekanbaru). Jom FTEKNIK, $4(2)$.

Puslitbang Pemukiman dan Balitbang. (2005). Pedoman Teknis Pemeriksaan keselamatan kebakaran bangunan gedung (Pd-T-11-2005-C).

Riadi, M. (2018). Teori Api, Tahapan Kebakaran dan Cara Pemadaman. Retrieved from https://www.kajianpustaka.com/2018/11/teori-api-dan-tahapan-kebakaran-dan-carapemadaman.html 
Suwanda, S., Hidayat, B., \& Hesna, Y. (2009). Evaluasi Penerapan Sistem Keselamatan Kebakaran Pada Bangunan Gedung Rumah Sakit Dr. M. Djamil Padang. Jurnal Rekayasa Sipil (JRSUnand), 5(2), 65. doi:https://doi.org/10.25077/jrs.5.2.65-76.2009

Trikomara, R., Sebayang, M., \& Mahmudah, R. (2012). Evaluasi Keandalan Sistem Proteksi Kebakaran pada Bangunan Gedung (Studi Kasus Gedung Kantor Bupati Indragiri Hilir). Jurnal Universitas Riau, 1-11.

Zulfiar, M. H., \& Gunawan, A. (2018). Evaluasi Sistem Proteksi Kebakaran pada Bangunan Hotel UNY 5 Lantai Di Yogyakarta. Semesta Teknika, 21(1), 65-71. doi:https://doi.org/10.18196/st.211212 